DOI: https://doi.org/10.47405/mjssh.v6i2.674

\begin{tabular}{|c|c|}
\hline 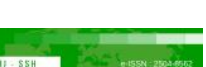 & Malaysian Journal of Social Sciences and Humanities (MJSSH) \\
\hline Malaysian Journal of & Volume 6, Issue 2, February 2021 \\
\hline (Mu-ssH) & e-ISSN : 2504-8562 \\
\hline & $\begin{array}{l}\text { Journal home page: } \\
\text { www.msocialsciences.com }\end{array}$ \\
\hline
\end{tabular}

\title{
Social Responses and Narrative Experiences of the Filipino Middle Class to the COVID-19 Crisis
}

\author{
Nicha Tovankasame' ${ }^{1}$ Czarina Labayo ${ }^{1}$ \\ ${ }^{1}$ Faculty of International Studies, Prince of Songkla University, Thailand \\ Correspondence: Nicha Tovankasame (nicha.t@phuket.psu.ac.th)
}

\begin{abstract}
The incessant spreading of COVID-19 disease has recently been the major concern to the Filipino since January 2020. The crisis becomes uncontrollable and impacts on all walks of life in terms of their routine living, working conditions, mental health, and social interaction. As observed in the past few months, the Philippine government has attempted to deal with the transmission of infection and economic predicament. However, there has been tremendous criticism towards the government's methods of solving the problems, and one of the controversial discussions is the inequity of offering assistance packages to socio-economic groups. This article seeks to grasp the perceptions of the Filipino middle class who are mainly excluded by the aid of the government from the COVID-19 crisis since they are misrepresented as capable of self-help and self-responsibility in the neoliberal economy. The results evidently show their responses and narratives to the crisis through dealing with behavioural and social adaptation and psychological coping strategies. In times of the pandemic with low awareness of the government, most middle-class people are still precarious because of the entire dependency on the financial system and employment security to maintain subsistence in the present and future.
\end{abstract}

Keywords: Filipino Middle-Class, COVID-19, disaster, economic uncertainty, Philippines

\section{Introduction}

This study aims to determine the responses of the Filipino middle class on the national government's initiatives which resorted to their exclusion in the context of COVID-19 pandemic. In the Philippines, the national government instigated the monitoring of COVID-19 in January of 2020, when the first confirmed fatality was reported in the Philippines by the World Health Organization (WHO). A Chinese national from Wuhan, Hubei province, where the virus was detected came to the Philippines already infected with the virus. COVID-19 cases rose as the local transmission was also determined by the Department of Health (DOH). The national government began tightening its screening of intru sion into the country in the early week of January and on February 2, 2020, imposed selective quarantine for returning Overseas Foreign Workers (OFW). It also implemented the mandatory accomplishment of Health Declaration Cards for all port individuals and established the novel coronavirus task. On March 8, due to the threat of COVID-19, President Rodrigo Duterte proclaimed the country in a state of a national emergency requiring all agencies to assist in combating COVID-19. Thus, the Inter-agency Task Force for Emerging Infectious Diseases (IATF-EID) was created to implement measures and guidelines on how to respond to the threat. The task force constitutes government representatives and the Armed Forces of the Philippines. Because of the rise of community transmission in the national 
capital region, (NCR), the national government implemented Enhanced Community Quarantine (ECQ) in Luzon and major cities in the island of Visayas and Mindanao. Under EQC protocols transportation was banned and all Filipinos were asked to stay home and work from home.

The focus of this study is the middle class who found themselves under the state of precarity. The World Bank (2020) describes that the global middle class is the social group who live with lower dependency, headed by individuals with higher education, and employed in quality jobs with higher wages, such as, governmental sector, services, and manufacturing sectors, or even own businesses. However, many studies found that the Filipino middle class is often characterized as self-reliant, selfsufficient, and able to cope during precarious situations, specifically in the time of the COVID-19 pandemic. This social group is expected by the government to find their strategies to survive during the crisis.

To alleviate the current precarious situation, the government receives from international organiza tion s such as Asian Development Bank (ADB) amounting to 5 million USD called Rapid Emergency Supplies Provision Project, which supports provisional food assistance for vulnerable households and workers in Luzon (ASEAN Policy Brief, 2020). The Bayanihan to Heal as One Act (hereafter the Bayanihan Act) issued on March 24, 2020. The households, estimated to be more than 18 million, living under the poverty line, will be able to receive $\mathrm{P} 5,000-8,000$ (\$97.45-155.92) for two months per month as financial aid as stated in this policy. The amount of $\mathrm{P} 275$ billion was contributed to the poorest of the poor and not every middle class would get monetary assistance. The middle-class recipients have to meet a certain qualification, for example, those who do the business and still have to pay for the loan. The Department of Finance mentioned that the needs of the middle class who are regularly employed have also been initially addressed under Republic Act (RA) No. 11469 or the Bayanihan Law will allow payments for their amortizations and loans to be extended and will give grace periods. The middle class that operates small businesses can apply for a subsidy, called emergency aid being rolled out by the government, through wage subsidies amounting to P35 billion, among other forms of relief assistance. Furthermore, an assistance package for the middle class employed or operating micro, small and medium enterprises (MSMEs), including a loan guarantee program for them.

To understand the worldviews of Filipino people in dealing with the COVID-19 crisis, it is significant to bring about a similar context of how they can cope with the natural disaster, which tends to be their major challenge in the living condition. However, the health crisis has recently become an obstacle for many people to strive for their employment, financial security, and social safety net. The concept of the Filipino middle class from the previous studies is brought to examine their dynamic characters from time to time. Moreover, it is interesting to study how the economic system influenced such dynamism. During the COVID-19 crisis, this study aims to explore the life experiences of the Filipino middle class since they are the social group who tends to be given the role of self-help in the uncertain economic system. Another purpose is to look into their responses to the national government's Bayanihan policy of the Filipino middle class since it is highlighted that the national government policy such as the Banahihan Act only includes a particular group of middle class such as entrepreneurs and debtors.

\section{Literature Review}

\section{The Culture of Disaster in the Philippines}

The Philippines is one of the southeast Asia countries, prone to natural disasters such as floods, typhoons, and volcanoes. In this regard, disasters have long been part of Filipino people and are culturally embedded over time. One of the many challenges of theorizing these two concepts, disasters, and cultures, is its multidimensional feature. Early in the twentieth century, the concept of disaster captured the interest of social scientists especially when Samuel Prince studied the implications for social change in the munitions explosions in Halifax harbour and looked into it as social structural research that didn't happen until after half a century. During that time, social scientists approach disasters as unpredictable and extreme happenings that dismayingly fell upon human communities. 
They considered disasters departures from the norm and contended that recovery from them was to return as quickly as possible to a pre-disaster status quo, at least in terms of visible damage or calculable duress. From the 1950s to the 1970s, interests cantered on the behaviour of the individuals and organizations in the warning, impact, and immediate aftermath stages of disasters. Little historical perspective and scant sociocultural pattern were taken into accounts (Oliver-Smith \& Hoffman, 1999).

Having mentioned the multidimensional feature of disaster, this study adapts the idea expressed by the anthropologists Oliver-Smith and Hoffman stating that disasters do not just happen, rather it takes place through the conjuncture of human population and a potentially destructive agent that is part of total ecological systems that unfold as processes over time. A disaster becomes unavoidable in the context of a historically produced pattern of "vulnerability," evidenced in the location, infrastructure, socio-political organization, production and distribution systems, and ideology of society.

Disaster studies bring significant contributions in the field of anthropology as the disaster itself has this expository relevance (Oliver-Smith \& Hoffman, 1999). Multiple types of disasters are becoming more frequent and more serious as communities become more vulnerable. When hazards threaten and disasters occur, they both reveal and become an expression of the complex interactions of physical, biological, and sociocultural systems. If the disaster is taken as a normal phenomenon, Jansen (1998) emphasized this common experience of disaster, this normalization of threat, may have been a significant factor influencing the development of cultures in the Philippines.

In order to allow the communities to acknowledge the constancy of the disaster and to manage its worst impacts, many of them resort to their coping mechanisms. Jocano (1999) stressed that one of the core cultural coping mechanisms of the Filipinos is what he refers to as that of pakikipagkapwa or being one with the other or with others' or 'being part of the group'. The concept is utilized interchangeably, most often, to refer to a character aspect like bayanihan and pakikisama though the emphasis is subtly different in each case. The meaning of bayanihan refers to toiling and carrying the burden on behalf of another person, and pakikisama means to break the notion of ranks or social status with their group without considering merit or personal gain. The shared community, also defined in an operational term as a neighbourhood is pivotal in providing support for the community members in times of crisis, even an upcoming disaster event (Jocano, 1969).

When communities are vulnerable and lack the capacity and resources to face the threats of natural hazards, disaster is inevitable. Collaboration between stakeholders is essential for sustainable disaster risk reduction (hereafter DRR). Local communities, government authorities, non-government organizations (NGOs), scientists, school communities, and faith groups all have a role to play. Communities are an important resource and constitute the frontline of action since they are most severely affected by, and the first to respond to, disasters. The NGOs often assist the communities in conducting community-based DRR. The bottom-up approach emerges through the actions of the community and its people. From the top-down, scientists and government authorities should provide support and facilitate access to sustainable livelihoods and means of protection (Gaillard, 2008).

Interestingly, the historian, Gregory Bankoff, wrote considerable studies on the role of disasters in human societies including resources and risk management. In his book, Cultures of Disaster, he mentioned that historically, the Philippines is one country where disasters are embedded in its culture. During times of disasters, Filipinos have always demonstrated the value of "bahala na" or "leave it to fate" sentiment which ideally means a sense of calculated risk. In behavioural terms, this is equally an active calculation of the odds as it is a passive sense of acceptance of one's fate. Nor is it without an element of faith either: faith in the efficacy of prayer and in the intercession of divine protection (Bankoff, 2003). Moreover, this is also about courage and daring and a sense of finely calculated assessment of the odds in god's hand, thus, the result is god's will.

The Filipinos are also known for their pakikipagkapwa or a sense of shared community. Often, it is defined as neighbourhoods, which will guarantee support for its members especially during times of personal travail or common hardship such as in an unfolding disaster situation (Jocano, 1975). Jo cano particularly identified the sense of humour shared by many Filipinos and their ability to laugh even 
during the worst calamity or disaster. Storytelling and swapping jokes with friends were perceived as an important means of dealing with angst, relieving stress, and overcoming anguish.

When a person says, "bahala na", the expression manifests that fate has already been decided even if one does not know the result, thus, there is no need to worry about something that is beyond your control, on the other hand, it also means that something or the situation is resources to deal with the hazards that confront them, as the government is often incapable of addressing the consequences of disasters adequately, and there are only limited technological solutions as to what are increasingly complex issues (Bankoff, 2009). During times of disaster, Filipinos`sense of volunteerism has always been lauded. Filipino people celebrated volunteer work as a form of accomplishment and a sense of expressing a "bayanihan" or a spirit of mutual help and cooperation (Guia, 2005, p. 376)

The question of whether the COVID-19 pandemic is a natural disaster surfaced since it occurs naturally, unexpectedly, and disrupts the normalcy of every population in the world. Revet (2020) points out that the ways in which the disease can be analysed is to look into the terms "crisis" and "emergency" addressed in remedial programs by many global health agencies. The crisis is explained in the sense of when a "temporary disruption" occurs in a normal state or situation. However, the goal of natural disaster restoration normally expects a return to "normal functioning". The strike of health crises, like the COVID-19 pandemic, has created different methods of a long-term process of recovery. It requires humanity to experience "abnormal functioning" as "new normal" ways of living, for example, wearing a mask and practicing social distance in public. The lockdown in many areas paved the way for the utilization of technology for distant meetings, online teaching, or virtual gathering among family members has become essentially increased and continuously carried out as an ordinary doing.

\section{The Economic Uncertainty of the Filipino Middle-class}

During the COVID-19 pandemic, the middle class tends to face the fluctuation of the economy most in the system since they are the social group that depends on the instability of the global economy and financial credibility. They are at the same time neglected by the government's aid due to the thoughts that they can be self-reliant in the economic system. To delve into the concept of the middle class in the Philippines, there have been discussions from various perspectives. The middle class first emerged in the 1930s when the economic opportunity opened for small-scale business owners due to the acceleration of national industrialization. Another new generation of the middle class was developed by an educational system that produced a large number of scholars and officials (Kimura, 2003). The way in which the Filipino middle class is uniquely rooted can be seen from the combination of American democratic instillation and Filipino nationalistic enthusiasm and consciousness. They were the emergent class to serve developmental purposes for specialization-based fields of instructing, public sector, professional and technical services, mainly located in the capital Manila.

However, another huge economic transformation happened in the 1980s when the Philippine government started implementing the neoliberal policy. The technocrats of President Aquino first brought about the draft dominated by the Reagan and Thatcher free-market system through structural adjustment, to solve the economic crisis of Macros (Bello, 2009). The policy has created the advanced governmental approach of "national industrialization" and "national democratic" economy. Although there have been massive criticisms toward the neoliberal policy by scholars on the negative consequences. The corruption, favouritism, and monopoly caused by the Filipino cultural roots of reciprocal ties between social classes, patron-client system, and oligarchy (McCoy, 1999) has also been considered as a "hindrance to democracy" (Seki, 2015, p. 1274), and the focal dilemma of implementing policy results in widening a huge gap of people in society. Regarding the positive results in terms of socio-economic development, it has increased the GDP from $\$ 49,095$ million in 1990 to $\$ 91,234$ million in 1997 and allowed the middle class to enjoy the deposit interest rate of $19.54 \%$ in 1990. Pinches (1996) explains this phenomenon as "the emergence of a 'new middle class', which composed of the growing corps of professional managers, administrators, and technical experts" (106). The democratization process and economic liberalization are significantly highlighted in their social 
life. It gave rise to the financial elevation and lifestyle upgrading of the Filipino middle class, and their spending power became the major source of national economic growth in due course.

The impression of the government toward the middle class is economically categorized as a social group who earns monthly P19,040 - 38,080 (Albert et al., 2018), tending to mislead the reflection of reality. The global economy has been a crucial factor in increasing the numbers of Filipino middleclass. Working abroad as transnational labourers in the educational industry and service sector would transform those in marginalized class to be high earners. As the free market allows any individual to participate in the field of entrepreneurial freedoms, it changed the traditional mindset of kinship bond, closed-knit community, and social classes, to become a society of polarized, fragmented, and individualized (Crompton, 2008). It is undeniable that neoliberalism has not just increased the physical mobilization of the Filipino migrants but has also transformed their social mobility to pursue the middle-class called the "new rich" (Pinches, 1996). In this regard, there are no definite explicative characteristics of the middle-class in the emerging era since they are "hybrid" and "overlapping" (Aguilar, 2003, p. 154) between social classes.

The neoliberal governmentality (Harvey, 2005), or the economic system in which they live, has a vital role in influencing the individuals of homo economicus to become a "self-enterprising subject" (Ong, 2006, p. 173) and being proactive in responding to the changes that are occurring in his environment (Gordon, 1991, p. 43). Thus, the capitalistic milieu shapes their behaviours to suit marketability and acquire self-employable skills for better opportunity seeking. To further identify such char acteristics, Seki (2012) points out that the Filipino middle class, who experienced "transnational social fields" between their home country and overseas, has constructed pendula identity due to a social practice of "distinction and differentiation" from others and their relations of social classes, conveying the concern of their equivocal characters in the context which global linkages involved (215).

Aside from the economic potency in driving the nation to develop, the Filipino politically known as being criticized in the public sphere. Historically, they used to gain political power in leading the nation's uprising against the dictator Marcos in 1986, and the president Estrada in 2001 (Thompson, 2020). The awareness of their rights of being responsive to political matters can represent their consciousness of other significant social issues. In order to further discuss whether the Filipino middle class would also be a social class that takes the role of being self-responsible in the matter of the COVID-19 crisis, it is important to not classify them by measurable income. But it is essential to scrutinize the matters of individuals' cultural background, socio-economic aspects, and political power that they are valued in particular domains.

\section{Methodology}

This is a qualitative research conducted during the emergence of COVID-19 in the Philippines from July to November 2020. The data are gained from two sources of gathering: firstly, document research on news announcements regarding the current situation of COVID-19, the government policies of remedial measures from COVID-19, and the reactions and implementations of policy on the situation. Secondly, since infectious cases were still active and found in many cities, the researchers used digital ethnography as the main research method through in-depth interviews online. Facebook messenger is the medium of communication with the informants. The research purposely selected three middle-class Filipino informants from three different groups of background in order to gather various perspectives. These informants are (1) a person who resides in the Philippines and has never lived abroad (2) a person who is transnational middle-class, living abroad for education or employment (3) a person who resides in the Philippines with an experience of staying abroad. Informal conversation was used in the interview to collect data regarding their living strategies and work impacts during and after COVID-19, the financial aids or supports from the Philippine government, the informants' perceptions towards the crisis and government's policies, and their anticipation of a post-COVID recovery. After the data gathering, all data were analysed and organized in the thematic form of presentation. The first-person style of writing is applied for perceptive accounts and insightful comprehensions. 


\section{Results and Discussion}

In this study, the data gathered by the researchers are analysed thematically. Three Filipino middle class were interviewed about their life experiences and working conditions during the COVID-19 pandemic. Focusing on how they cope with their mental health, psychological state, and spiritual aspect, they were also asked about their transitions and adaptations to the "new normal" way of life. Moreover, the participants were asked about their perceptions of the Philippine government's initiatives such as the Bayanahan policy.

\section{Life under the Enhanced Community Quarantine (ECQ)}

Carla, 35 years old is a Filipino middle-class returnee. She spent five years in Japan for her graduate studies and on March 16th, 2020, she went back to the Philippines. This was also the first day where the government announced its lockdown otherwise known as Enhanced Community Quarantine (ECQ) in Metro Manila and the major cities in the country. Because the government imposed a closing of borders for each province and city, she was stranded for two months in Manila and was waiting for the government to ease their rules. She shared that she experienced challenging situations like access to transportation, strict city-to-city border implementation, and the atmosphere gives off a frightening feeling. She said,

"So, upon landing at Narita Airport, I observed a very quiet and empty NAIA airport which is not its usual scenario. My first challenge was the transportation that I can use so I can go to my friend's house. No public taxis or buses. Thankfully, a private car rental online was available and cost me 3,000 PHP from the airport to Makati. My friend accommodated me in her condominium which is located between the boundary of the cities of Taguig and Makati. Uniformed men were very visible outside. It felt like there's an upcoming war, a military coup, or political unrest. They were military men who checked the boundaries of Taguig. Since we were technically residing in Makati, however, the convenience stores in Taguig just stepped away. We tried to negotiate and explain our situation, but the military men were firm and strict not to let us enter. However, we managed to finally convince them and allowed us to enter when my friend showed her work-ID, proving that she is working on the premises of Taguig. After that crazy (things), we panicked and bought the essential things, like water, instant noodles, canned goods, bread, and biscuits. It was as if we're preparing for war, or a disaster, or something vague. We also bought medicines. The government was firm on forcing people to stay home while the COVID cases were rising day after day. By June, the local government of my hometown announced that they were already allowing their residents to come back, and we were labelled as locally stranded individuals. However, there are documents that are needed to be accomplished before entering my hometown -- a medical certificate, and a clearance from the barangay, proof of residence. I didn't waste time and accomplished it right away. I've asked our driver to fetch me. The checkpoint in Sorsogon was time-consuming. The military personnel checked all our body temperature, documents, verified the plate number of our car. Later on, we were asked to follow the convoy led by the local hospital's Ambulance to take us to the health officers stationed at the Sorsogon State College. For our last stop, we got out of the car, filled out health forms and two nurses welcomed us. They also checked our temperature, asked about COVID-19 symptoms, and informed our barangay leaders of our arrival. The nurse gave us a go signal to start our 14-day quarantine. I cannot go out of my home for 14 days. Also, the local health officer conducted visits every day to check my situation. Ifelt relieved that I was finally home, with my parents, in the comfort of my home even if I cannot go out. On the 14th day of my home quarantine, I was given the certificate 
DOI: https://doi.org/10.47405/mjssh.v6i2.674

by the barangay to officially state that I completed the quarantine, and I can go out of my home. (Carla, personal communication, July 30, 2020)

Moreover, the second participant Jasmine, 35 years old, is a Filipino middle class who is living abroad for two years and is working as an English teacher at an International School in Indonesia. According to her observation, the COVID-19 cases in Indonesia are still increasing but the people are dealing with it normally. Her main adjustment was in her work where her school transitioned to online classes. She mentioned that both the students and teachers experience challenges with this new way of teaching. She said,

\begin{abstract}
"I am working as an English teacher, particularly teaching English as a Second Language for Grade 7th and Grade 8 students. Here in Indonesia, the COVID-19 cases are still high, and they are dealing with it normally like the business centres are open. The malls are open too. I observed that Indonesians can still travel. As one of my students is in Bali right now doing online learning while in Bali. Seating on the sand, listening to the teacher online. So, some are treating this whole thing as normal. For our school, we're doing home-based learning, it is an online class. It started in July, our first semester. By January next year, we are planning to transition to blended learning. But we have to survey the parents first if they are okay with face-to-face teaching. As a teacher, I'm a relational person, and doing an online class could be easier. I can just turn on my laptop and I can see my students on the screen. But the connection is not there. I've asked my students what they're feeling about this online class and the majority of them are saying that they are tired, bored, and unmotivated. The reason for this is because they can't see their friends, they just stare at the screens and it does limit their creativity. Kids are naturally creative. Sometimes, the kids are unresponsive, when I call out, like 'hey are you there?!' and then no one is responding. Their attention span is really short. The strategy of transitioning to home-based learning was challenging because even us teachers were not prepared. For example, we experience challenges in grading our students. We are not sure if the test papers they are turning in are independently done by them. During examinations, they are required to use two cameras, so we can check their background. We relied on honesty. Academic dishonesty is another issue. Some students are not aware of citations and would copy from different sources the website." (Jasmin, personal communication, August 13, 2020)
\end{abstract}

Meanwhile, Ryan, the 3rd participant is 38 years old, is a Filipino middle class based in Metro Manila. $\mathrm{He}$ is working as an associate dean in a private university in the Philippines. He narrated the challenges he faced during the lockdown, coping strategies, as well as the different groups he joined to overcome the difficult situation. He stated,

\begin{abstract}
"I believe I am okay during the first few months of the lockdown, it was difficult for me because I'm not used to not going out. I like going out after work before Covid happens. I feel like I'm being controlled by the laws of the government. Especially during March and April, I felt a little depressed, but they say it's cabin fever. But when we started working online, I think it was okay for me since I get to be busy with some things and it helped me as well. It took a while to adjust. I get irritated when my boss asks me to join a meeting. I have personal issues when responding to emails. But later on, what made me accept this reality when I heard that other universities and companies are shutting down, I told myself that I have to be grateful for this. " (Ryan, personal communication, August 28, 2020)
\end{abstract}

\title{
Transitions and Adaptations in the New Normal
}

The three Filipino middle class experienced various transitions that they needed to adapt to while living in the "new normal". Aspects in the socio-economic, mental, and psychological, and spiritual 
were discussed as these aspects constitute their well-being. All of the participants have stated that the first part of the lockdown was the most challenging and as the days go by, they were able to cope and adapt to their situation. One of the main challenges faced by Carla upon her return to the Philippines is unemployment and underemployment. Because of the COVID-19 pandemic, large companies and even academic institutions have declared their freeze hiring policy. She stated,

\begin{abstract}
"Since I just finished my graduate studies in March, searching for a job has become difficult. I am aiming for something permanent and secure, like to build a career in international companies or academic institutions. I was faced with the harsh truth ---the companies that I intend to apply to just announced that they are not hiring because of this health crisis. To be practical, I needed to look for temporary jobs. I have to make do with what is available and accepted jobs online. This situation, not knowing the future, contributed significantly to my anxiety and stresses."
\end{abstract}

Meanwhile, for Ryan, because worked in the institution for more than a decade, he gained tenureship in his job. Being part of the administration level, he was confident that won't be laid off. However, he is directly affected by the unemployment of the people around him, like his friend and family members because they relied on him for monetary support. He shared,

"I'm confident because I'm at the administration level. I'm working with De La Salle University as an Associate Dean of Student Affairs. I'm confident if the university would lay off some employees, I'm confident that I'm not part of that list. So perhaps those who are in the rank and fire position, are the ones most affected. But it's very true in terms of funding and how we do things here at the university. Our budget is really tight this time. Because some economists project that the economy in the PH should be better in the next 3 years, so we can recover in the next 3 years. I also feel that I'm affected even though I still earn because a lot of my friends are jobless. So, they would express like can I borrow, even to some of my family members. Well. at home, actually they are really affected, and our family's business is about consumption, water, and food. So, it actually is not so much affected and not that bad. Before I was selling cocoa beans, pure chocolate came from our province. I used to sell that. But not in the mainstream like Lazada or other selling platforms. But during this lockdown, because I have enough time, I tried it and it's growing bigger. So, I asked some of my friends to come here to assist me because I'm so busy with my work. And business is growing strong and big actually now with that chocolate. So before and now I can sell about maybe 200 - 300 packs a month, and that's equivalent to about in terms of revenue, a gross equivalent to about 40000 - 50000 peso, for me that something. I was surprised I have this kind of thing in my life during this lockdown.

\title{
a. Psychological aspect: virtualgroup activities relief for anxieties and stresses
}

In the early parts of the lockdown, all the participants were experiencing the negative emotional impact of the COVID-19 pandemic. Staying at home most of the time and having no clue when this pandemic will end made them feel insecure, but they have also come up with strategies to overcome these emotions. For instance, Carla mentioned that her activities are done virtually, for example, catching up with friends and family occasions are held online. Carla mentioned,

"I consider myself a very social person, an extrovert who likes to interact with friends and family a lot. And so, being stuck at home makes me uneasy and restless. I also removed the negative triggers which I see online. I started unfollowing news updates and people who were too passionate in voicing out their concerns in the online sphere. Fortunately, my friends started virtual meetings to update each other's lives also, family celebrations like birthdays were also celebrated virtually too! There were a lot of changes during this pandemic. Somehow, it makes me 
DOI: https://doi.org/10.47405/mjssh.v6i2.674

paranoid to go out of my house. It is different and awkward at first because we are not used to it."

Moreover, Jasmine shared that she panicked when she got sick at the onset of the lockdown. Fearing that she has the COVID-19 symptoms, she felt paranoid. She said,

"I felt I got the virus because I got chills, and my body was aching, and I have the Covid-symptoms. It was kind of alarming for me. I was asking my friends to pray for me. I was so paranoid during that time. I was kinda anxious and sad but right now, it's hard to define what I feel because it changes. I just want to focus on the blessings and feeling more grateful. I am not as anxious as before. I think I've already overcome the anxiety. This time, I am more hopeful because there is a vaccine already, and I just want to focus on the positive things because otherwise, I'm going to be miserable."

Also, for Ryan, he keeps himself productive at home, he focused his attention on exercise and online training. He mentioned,

"First few months are probably exercises at home. I even bought the band, instead of going to the gym, you have like robes to use physical exercises here. So, I got one here. I also attended some online training and more one, my skill is also my resilience. I prepare myself on how to be resilient, so I attended a lot of training and seminars. That helps me a lot lately."

\section{b. spiritual aspect: online mass and meditation time as coping mechanisms}

The three Filipino middle class are all practicing Roman Catholic and during this lockdown, they joined the online church service held every Sunday. Carla mentioned,

"As a Catholic, we used to attend Sunday mass in the church but because the mass gathering is not allowed, we resort to online mass. Although it is more convenient to hear mass online, however, the distractions are also many inside the house."

Furthermore, Ryan discovered that during this lockdown, he became more spiritual because he has more time to reflect and do meditation, aside from practicing his Catholic traditions. He shared,

"I'm a Catholic. I'm a Christian. But I also practice some Buddhist (activities). I do meditation something like that. But during this time, I do practice meditation rather than religious practice. I can only attend Holy mass online. But the first few months that one also my activity is to do meditation. I also follow the different ways of meditation. Even the modern way of doing the meditation introduced by pra (monk in Thai language). It was difficult for me to pray as a Christian as a Catholic because we need to go to church. But my alternative was to actually prepare an altar. I believe I became a spiritual person during this lockdown.

\section{Perception Towards GovernmentResponses to COVID-19 Crisis}

The three Filipino middle class claimed that the management of the COVID-19 pandemic in the Philippines is inadequate and unsatisfactory. Carla highlighted that there is a disconnect in the implementation of policies among government agencies. She mentioned,

"I feel that they are causing much confusion to the Filipino public. I think every local government has its own rules and like me, traveling from Manila and going back to the province has to write emails to five different government offices (only one replied) as to how to go about the trip." 
Jasmine also added that the middle class abroad in the Philippines is losing their jobs and it is a serious problem that must be given attention by the national government. She further stated,

\begin{abstract}
"I used to have a Twitter account, but now, it was stressful for me. So much bad news, I had to deactivate it. So, to know what's going on in the Philippines, I just ask my family and friends. News in social media is depressing. I deactivated my Facebook and Twitter accounts. The Philippine Government right now I think has misplaced priorities. We have so many COVID-19 cases right now. They are not handling it well. It adds to the anxiety of the Philippine people. For an Overseas Foreign Worker (OFW) like me, knowing this news doesn't help me because it doesn't give me peace of mind. The way the government is handling the situation and judging from what my family and friends are telling me, they are not managing it so well. People are losing their jobs. Poor people are getting poorer. The local government is transparent, specifically in my province. Everybody receives help. I cannot say that to the national government. I do not agree with the middle class being excluded by the government. I do not agree with the middle class being excluded by the government. Because there is also the middle class who lost their jobs, and also the middle class who are relying on the paycheck to paycheck. They also need assistance. You cannot generalize the middle class. You cannot assume that their salary is stable, some of them have shrunk. So, I think that the government should not exclude us. We're also paying our taxes.
\end{abstract}

Meanwhile, Ryan shared that the lack of accurate data on the ground was one of the main challenges of the government. Without the updated number of the poor, implementation of projects is not possible. He mentioned,

\begin{abstract}
"It was like 2016 data only, so how shameful the government Philippine is! They cannot update the data, and this is very important. They couldn't count the numbers of the poorest of the poor. So that is why the way they implemented it is they ask the local government now, they try to coordinate with the barangays and to count how many people are very poor and only during this time. For me, that was like a shame. That was not a good implementation plan. Even in that aspect, they were still trying to get the data on the ground, and so they have the budget already. So, I could understand that the budget couldn't be enough because I'm sure we don't know that their count, for example, is about 16 million very poor people in the PH, perhaps it increases already, like an increase to $18-20$ million, so we don't know. For me, data is very important, and our government did not do well in that aspect. I think there is no problem with the implementation and the plan in the national government, but the problem is at the local government down to the barangay because the data is not that accurate coming from the national government as well. I mean, I always see that the problems are in the local government, the implementation on the ground."
\end{abstract}

\title{
Middle-Class Response to the NationalGovernment's Initiative
}

One of the criticisms against the national government is biased towards regularly employed citizens and selective strategy in implementing their policies. The middle class is the social group that is often excluded from the benefits. As highlighted by the narrative of Ryan, he shared that the Bayanahan policy. policy, which the government initiated to delay the payments and add zero interests for mortgages made by the middle class is acceptable, but he would rather not avail of the program because, at the end of the day, he would still pay for the entire amount at some point. He also mentioned that the local government in Manila gave out cash for every household but since he resides in a middle-class village, they did not receive the amount and the food package that is meant to be given to everyone. He said, 
"In local cities and municipalities there are supports given to individuals or homes like in Manila, but the implementation was not that good. For example, our city of Manila also provides support like a thousand or 3000. I think in Manila 3000. And I know that I'm Middle class. I can afford it, but I can avail of that. But our village here did not release that amount. Some of my colleagues nearby and neighbours received that amount. I questioned some village head here or the chair of the village, ah you know, that is just I heard but I cannot confirm. I even texted or tweeted the city mayor. I think I asked about the support given to the people in Manila, like can everyone avail? Something like that. But when I shared this with my friends, they laughed at me and they told me what? You did that? How dare you? Because you know? For me, it was not just my need, but I just want to be sure that they use their money properly. I just want to make sure that they didn't abuse. But in my case, in my barangay, in my village, they didn't implement it well. And I'm a registered voter here. And my cousin for example lives in Manila, not a registered voter. He got 3000 pesos, and how come? I'm a registered voter here and I didn't get any support. I only got like two kilos of rice and a pack of spaghetti and noodles. Actually, I have rice here and I can actually get the spaghetti. What can I do with it, some canned goods? I'm not into canned goods during that time because I'm trying to be healthy. I actually gave them away to others. Actually, that's what happened. I received donations twice, donations. But I don't need these, so I got that spaghetti even until now I didn't cook. It is still there. I couldn't feel that support coming from the government to the middle class. Perhaps the businesses I think get a bigger share because I think taxes were cut off. There were benefits I think to wealthy people here. But for our middle class, I couldn't feel so much support really from the government. My contribution is to work and continue paying taxes because our government needs the money. But our taxes are alright for my research incentive. For example, I was supposed to get 100,000 pesos, but I only got 70000 pesos. I said Oh I hope this is for the tax. This is to support the Filipino people. It's just alright for me. And then my business as well, because I' $m$ helping my co-Filipinos here. And at the same time, I'm also helping. Because I don't get the gains here. I would give the gains to my sister who is also doing these things in the province on the beautiful island of Bohol. For me, it's one of my contributions and to be strong and positive. Not to criticize so much on the government, but to support and help, I think that's one contribution of the middle class. Not to look for problems, to get angry, or enraged asking the government and others, I think my support can do as a middle class.

Moreover, some of the Filipino middle class have no expectation from the government for assistance. As Carla highlighted that the government fund is not enough to help the poorest poor, and so, there is a need to be self-supporting. She said,

"The bayanihan cash incentive for the poor was not enough and the national government, since they are not providing cash incentive during the lockdown, the local businesses are starting to feel its toll. I feel that as part of the middle class and having a family business, we do not expect the government to give us cash but to allow the non-essential to open up. The lockdown means the closure of our printing business. Fortunately, my province has eased the lockdown because of lower COVID cases and in June the business reopens. Yet, I feel that the middle class does not expect that the government will focus on providing us aid because how can they do so when the poor themselves aren't given enough help? The government can no longer provide the necessary assistance to the poor, do those in the middle class still expect help from the government? So here in the Philippines, the middle class needs to be self-sufficient. You should no longer be a burden to the government. The packages are not enough. It should be more especially for the poor. It should be every month at least for that package. But I also would want to understand that the government couldn't afford any more if they provide monthly 
to be given to the poorest of the poor. So many problems to see. But I think on the side of the PH, I believe that they're thinking big, they're planning well, but it's not enough. They also got loans from ADB, Asian Development Bank. But I think it's still not enough because if we loan too much there are also repercussions in the future. So, they are very careful as well in that aspect.

In times of the COVID-19 crisis, the national government instigated the Bayanahan program to help not only the poorest of the poor but also the Filipino middle class, particularly those who are regularly employed. The government helped ease their burden by extending grace periods of paying their amortizations and other forms of loans. However, it is important to point out that the government fails to address those types of the middle class who are unemployed, the returnees, and those who are working abroad. Based on the narratives of the three Filipino middle class in this study, the disconnect between them and the government and their reliance on their coping mechanisms are apparent. As a result, while the government aims to acknowledge the middle class in the Bayanahan project, it translated to even furthering the gap of exclusion between them.

\section{Conclusion}

Since the Philippines is known as the country that normally encounters the crisis from natural disasters, the COVID-19 pandemic has become another crisis, doubling the hardship of Filipino people in all levels. In this respect, the health crisis happens to remain for quite a long time and affects other aspects of livelihood as the plight of infection cannot be solved and the active cases are still found. The final section deals with the conclusion of how responses of the Filipino middle class concerning the COVID-19 pandemic can actually be scrutinized. There are two main points of view to reveal. Firstly, when the pandemic occurred and the government started to implement the lockdown, it became difficult for all to adjust themselves to the behavioural changes, such as avoiding social gatherings in public places, having less physical contact with families or friends, and restricting travels across regions. The situation has been even worse when the government urged people to stay home with no effective methods to cease the spread of disease, as well as financially support the vulnerable ones. During the hard times, people have undergone the suffering of jobless conditions worrying about the hopeless future of being employed or finding resources to secure their life. This highly affects mental health in psychological distress and everyday anxiety. The society of uncertainty tends to reflect the similar results of dealing with the risk of neoliberal capitalism and disaster. Living under financial insecurity and life instability, later on, becomes part of the Filipino people requiring them to find self-strategy to cope with it and learn how to protect their community on their own (Jocano, 1999).

Secondly, the long-term crisis has recently become a new obstacle for the government to develop the national economy since they have to spend a large portion of the finances to resolve the crisis and ease citizens. However, the government just focuses the monetary assistance on the poorest of the poor as it is noticed from the cash-transfer program. The middle class is represented as capable of dealing with economic challenges themselves, therefore they can be self-assistant and should be self-responsible for such unexpected circumstances. However, the middle-class is a precarious group in the capitalist economy. They still need to pay for their daily necessities and rely on a paycheck to paycheck. The term bayanihan, utilized by the government to engage the spirit of Filipino, and tend to misinterpret the authentic definition. The implementation has failed to empower the vitality of all social groups' communal unity and cooperation from the bottom up, but the government utilizes it as a buzzword in the sense of top-down manner to selectively assist the poorest of the poor. As the informants of this study mentioned, the government has managed the crisis with the "misplaced priority", which augments the national predicament of pandemic and economy. In order to coordinate with the local government for the policy implementation, they lack "concrete data on the ground" to generate the accurate numbers of recipients and set up plans of financial recovery to alleviate all groups in a longterm crisis. 
In times of disaster, the study further suggests that the Filipino middle-class respond flexibly towards the environmental transition and regulative coercion. Noticing from the home-based working and online religious practices, it entails the abnormal ways of lifestyle adaptation to lessen the mental effects and find new meanings of the actions to accept the reality of change. The study reached the point that the Filipino middle can easily flow in some certain situations with complex thought. Some of the Filipino middle class are capable of shifting their role from the beneficiary to the contributor, working as a volunteer to support the people in need. Some even do not expect help from the government anymore, but they find their additional sources of income. These are the consequences of the COVID-19 crisis that has not affected the national securities in terms of health and finances, but also those of the middle-class who are hopeless and precarious in the system.

\section{References}

Aguilar, F. V. Jr. (2003). Global Migrations, Old Forms of Labor, and New Transborder Class Relations. Southeast Asian Studies, 41(2), 137-161.

Albert, J. R. G., Santos, A. G. F., \& Vizmanos, J. F. V. (2018). Defining and Profiling the Middle Class. Philippine Institute for Development Studies. Retrieved from https://pidswebs.pids.gov.ph/CDN/PUBLICATIONS/pidspn1818.pdf

ASEAN Policy Brief. (2020). Economic Impact of Covid-19 Outbreak in ASEAN. Association of Southeast Asian Nations (ASEAN). Received on 28 September 2020, from https://asean.org/storage/2020/04/ASEAN-Policy-Brief-April-2020_FINAL.pdf

Bankoff, G. (2003). Cultures of Disaster: Society and Natural Hazards in the Philippines. London: Routledge.

Bankoff, G. \& Dorothea H. (2009). The Politics of Risk in the Philippines: Comparing State and NGO Perceptions of Disaster Management. Disasters, 33(4), 686-704. https://doi.org/10.1111/j.14677717.2009.01104.x

Bello, W. (2009). Neoliberalism as Hegemonic Ideology in the Philippines: Rise, Apogee, and Crisis. Focus on the Global South. Retrieved from https://focusweb.org/neoliberalism-as-hegemonicideology-in-the-philippines-rise-apogee-and-crisis/

Crompton, R. (2008). Class and Stratification (3rd ed.). Cambridge: Polity Press.

Gordon, C. (1991). Governmental Rationality: An Introduction. In G. Burchell, C., Gordon, and P. Miller (Eds.). The Foucault Effect: Studies in Governmentality (pp.1-51). Chicago: University of Chicago Press.

Guia, K. (2005). Kapwa: The Self in the Other: Worldviews and Lifestyles of Filipino CultureBearers. Pasig City, Philippines: Anvil Pub.

Harvey, D. (2005). A Brief History of Neoliberalism. NY: Oxford University Press.

Gaillard, J. C. (2008). Differentiated Adjustment to the 1991 Mt Pinatubo Resettlement Program among Lowland Ethnic Groups of the Philippines. The Australian Journal of Emergency Management, 23(2), 31-39.

Jansen, K. (1998). Political Ecology, Mountain Agriculture, and Knowledge in Honduras. Amsterdam: Thela Publishers.

Jocano, F. (1969). Youth in a Changing Society: A Case Study from the Philippines. Youth and Society, 1(1), 73-89. https://doi.org/10.1177\%2F0044118X6900100105

Jocano, F. (1975). Slum as a Way of Life: A Study of Coping Behavior in Urban Environment. Quezon City: University of the Philippines Press.

Jocano, F. (1999). Working with Filipinos: A Cross-Cultural Encounter. Metro Manila: PUNLAD Research House.

Kimura, M. (2003). The Emergence of Middle Classes and Political Change in the Philippines. The Developing Economies, 41(2), 264 - 284. https://doi.org/10.1111/j.1746-1049.2003.tb00941.x

McCoy, A. W. (1999). An Anarchy of Families: State and Family in the Philippines. Manila: Ateneo de Manila University Press.

Oliver-Smith, A. \& Hoffman, S. (1999). The Angry Earth: Disaster in Anthropological Perspective. New York: Routledge.

Ong, A. (2006). Neoliberalism as Exception: Mutations in Citizenship and Sovereignty. London: Duke University Press. 
DOI: https://doi.org/10.47405/mjssh.v6i2.674

Pinches, M. (1996). The Philippines' New Rich: Capitalist Transformation amidst Economic Gloom. In R., Robison, \& D., Goodman (Eds.). The New Rich in Asia: Mobile Phones, McDonalds and Middle-class Revolution. (pp. 105-133). London: Routledge.

Revet, S. (2020, November 5). Covid-19: A Natural Disaster?. SciencesPro. Retrieved from https://www.sciencespo.fr/en/news/news/covid-19-a-natural-disaster/4889

Seki, K. (2012). Difference and Alliance in Transnational Social Fields the Pendular Identity of the Filipino Middle Class. Philippine Studies: Historical \& Ethnographic Viewpoints, 60(2), 187221.

Seki, K. (2015). Capitalizing on Desire: Reconfiguring 'the Social' and the Government of Poverty in the Philippines. Development and Change, 46(6), 1253-1276. DOI: 10.1111/dech.12200

The World Bank. (2020). The Middle Class in the Philippines: An Exploration of the Condition for Upward Mobility. Washington DC.

Thompson, M. R. (2020). Middle-class Remorse: Re-embracing Liberal Democracy in the Philippines and Thailand. Global Asia, 15(1), 60-64. 